SJ Quinney College of Law, University of Utah Utah Law Digital Commons

2017

NEPA and the Energy Policy Act of 2005 Statutory Categorical Exclusions: What Are the Environmental Costs of Expedited Oil and Gas Development?

Mark Capone

John C. Ruple

Follow this and additional works at: https://dc.law.utah.edu/stegner_pubs

Part of the Environmental Law Commons, and the Natural Resources Law Commons 


\section{NEPA ANd THe Energy Policy ACT OF 2005 Statutory Categorical Exclusions: What ARe the ENVIRONMENTAL COSTS OF EXPEDITED OIL AND GAS DEVELOPMENT?}

\section{Mark K. Capone* \& John C. Ruple+}

Introduction 372

I. Background 375

A. The Bureau of Land Management and Oil and Gas Development. 375

The BLM in Wyoming 377

B. The National Environmental Policy Act (NEPA) 378

C. Section 390 of the Energy Policy Act of 2005 380

The BLM's Failed Attempt to Adopt New Section 390 Guidance.. 381

II. Methods 383

A. Geographic Scope and Data Acquisition ...................................... 383

B. Variables for Analysis 384

Initial Surface Disturbance as an Indicator of Environmental Impact

C. Dataset.....

D. Data Analysis 386

$*$ Attorney Advisor, Office of the
U.S. Department of Commerce.

+ Associate Professor of Law (Research) \& Wallace Stegner Center Fellow, S.J. Quinney College of Law at the University of Utah.

The authors would like to thank Professor Robert Keiter for his careful review of and thoughtful comments on drafts of this paper. The authors, however, are solely responsible for the opinions, recommendations, and any errors or omissions contained herein. Furthermore, the views and opinions expressed herein do not reflect those of the National Oceanic and Atmospheric Administration or the Department of Commerce. 
III. Results 387

Comparison of Surface Disturbance for CEs, EAs, and EISs 389

1. ANOVA Results 389

2. Components of Initial Surface Disturbance 390

IV. Discussion 391

A. Comparison of Environmental Effects for Different Levels of NEPA Compliance. 391

B. Specific Problems in Section 390 CE Implementation 393

1. Sundry Notices. 393

2. Type 3 CEs Tiered to RMPs 395

3. Type 3 CEs Tiered to Master Leasing Plans 396

C. Recommendation to the BLM 396

Conclusion 399

\section{INTRODUCTION}

More than a decade ago, concerned that National Environmental Policy Act $(\mathrm{NEPA})^{1}$ compliance caused delays in permitting oil and gas $(\mathrm{O} \& \mathrm{G})$ development on federal land, Congress enacted Section 390 of the Energy Policy Act (EPAct) of $2005 .^{2}$ Section 390 is intended to expedite the environmental review of $\mathrm{O} \& \mathrm{G}$ development projects on federal lands. ${ }^{3}$ To effectuate that end, Congress created several statutory categorical exclusions (CEs) to NEPA that apply to O\&G development. ${ }^{4}$

Prior to the EPAct, the Bureau of Land Management (BLM) would permit new O\&G development after conducting an Environmental Impact Statement (EIS) or Environmental Assessment (EA). ${ }^{5}$ EISs and EAs were

1. National Environmental Policy Act, 42 U.S.C. $\S \S 4321-47$ (2012).

2. Energy Policy Act, 42 U.S.C. $\$ 15942$ (2012).

3. Id.; see also W. Energy All. v. Salazar, No. 10-CV-237F, 2011 WL 3938240, at *2 (D. Wyo. Aug. 12, 2011) (noting that the EPAct was passed to address long-term energy challenges, including to expedite oil and gas development in the United States).

4. $\quad 42$ U.S.C. $\$ 15942$.

5. U.S. GOV'T ACCOUNTABILITy OfFICE, GAO-09-872, ENERGy POLICY ACT OF 2005: Greater Clarity NeEded TO ADDRESS CONCERNS WITH CATEGORICAL EXCLUSIONS FOR OIL AND

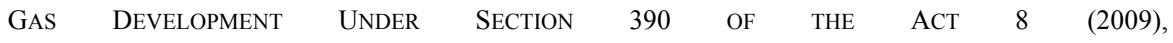


the only NEPA compliance option available to the BLM because the agency had not promulgated regulations creating CEs for O\&G projects. ${ }^{6}$ After the EPAct was passed, the BLM began permitting a substantial number of O\&G wells using the less rigorous CEs provided in Section 390. In fiscal years 2006 through 2008, the BLM used Section 390 CEs to permit approximately $28 \%$ of all wells nationally. ${ }^{7}$ States, members of Congress, and environmental groups have expressed concerns that the Section 390 CEs would lead to otherwise avoidable environmental impacts by circumventing conventional NEPA review. ${ }^{8}$ This article reviews 189 NEPA decisions and assesses whether the EPAct's CEs result in environmental harm that could have been avoided had the projects undergone EA or EIS review.

O\&G development on federal lands must comply with NEPA. ${ }^{9}$ An EIS is required for "major Federal actions significantly affecting the quality of the human environment." ${ }^{.10}$ An EA may be completed in circumstances where the project will not have significant impacts or if the agency is unsure whether the project will have a significant impact. ${ }^{11}$ Alternatively, an administrative CE may be completed where, pursuant to its rulemaking authority, an agency identifies types of actions that "do not individually or cumulatively have a significant effect on the human environment." ${ }^{, 2}$ In the

http://www.gao.gov/new.items/d09872.pdf [https://perma.cc/3TQM-XYUQ] [hereinafter GAO EPACT REPORT].

6. See Bureau of Land Mgmt., Dep'T. OF the Interior, H-1790-1, National ENVIRONMENTAL POLICY ACT HANDBOOK 13-20 (2008) [hereinafter NEPA HANDBOOK] (listing department and bureau CEs); W. GOVERNORS' ASs'N, PROTECTING WILDLIFE MigRATION CORRIDORS AND CRUCIAL WILDLIFE HABITAT IN THE WEST 1 (2007), https://www.westgov.org/images/dmdocuments/wildlife08.pdf [https://perma.cc/Y6ME-FVMG].

7. U.S. GOV'T ACCOUNTABILITY OFFICE, GAO-11-941T, ENERGY POLICY ACT OF 2005, BLM's USE OF SECTION 390 CATEGORICAL EXCLUSIONS FOR OIL AND GAS DEVELOPMENT 6 (2011), http://www.gao.gov/assets/130/126915.pdf [https://perma.cc/WR44-5727] [hereinafter GAO SECTION 390 REPORT].

8. Impacts to Onshore Jobs, Revenue, and Energy: Review and Status of Sec. 390 Categorical Exclusions of the Energy Policy Act of 2005: Oversight Hearing Before the Subcomm. on Energy \& Mineral Res. of the H. Comm. on Nat. Res., $112^{\text {th }}$ Cong. 7 (2011) (statement of Rush D. Holt, Ranking Member, Subcomm. on Energy \& Mineral Res.) ("The categorical exclusions established in Section 390 to expedite the approval of oil and gas drilling permits were unnecessary and unwise.... [Section 390 exclusions] cause environmental impacts, such as ozone levels that have reached or exceeded allowable levels and habitat fragmentation that has harmed... wildlife in the West.") [hereinafter Holt Statement]; W. GOVERnORS' Ass'N, POLICY Resolution 07-01:

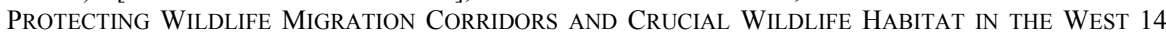
(2007) (calling for the amendment of the EPAct's Section 390 "to remove the categorical exclusion for NEPA reviews for exploration or development of oil and gas in wildlife corridors and crucial wildlife habitat").

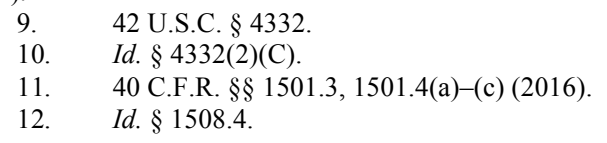


context of O\&G development, the BLM may also use one of the EPAct's statutory CEs. ${ }^{13}$

The BLM's use of the EPAct CEs raises numerous questions. First, the BLM initially took the position that these statutory CEs "differ substantively from administrative categorical exclusions: whereas administrative categorical exclusion[s] must have no significant environmental impact, there is no specific requirement that [S] ection 390 [CEs] have no such impact." 14 This means that Section 390 CEs could be used to expedite well permitting even when the wells would have a significant impact on the human environment. In practice, however, BLM field offices often elect to do an EA "in cases where projects seem politically controversial or may have a significant effect on wildlife." 15 Field office hesitance to use Section 390 CEs for certain projects may be "because [the] BLM fears litigation from environmental groups." 16 Apparently, many field office employees view completion of an EA or EIS as "more expedient than using a potentially controversial [S]ection 390 [CE] that may be litigated." 17

Second, Section 390 of the EPAct does not require public notice of proposed projects for decisions authorized under a CE. ${ }^{18}$ This has led to differing approaches by BLM field offices, with some offices providing public notice and opportunity for comment and others "not publicly disclos[ing] their decisions ... and, in fact, requir[ing] the public to file Freedom of Information Act requests to identify which projects BLM approved using [S] ection 390 categorical exclusions and to obtain copies of approved [S]ection 390 [CE] decision documents." ${ }^{\prime 9}$

Third, Section 390 CEs encourage a piecemeal approach to O\&G development. ${ }^{20}$ Because Section 390 CEs offer a relatively quick method

13. 42 U.S.C. $\S 15942$.

14. GAO EPACT REPORT, supra note 5, at 35. In a guidance memo, the BLM explained that $390 \mathrm{CEs}$ were established by statute and not under the Council on Environmental Quality procedures set out in 40 C.F.R. $\S 1507.2$ and $\S 1508.2$. BUREAU OF LAND MGMT., DEP'T OF THE

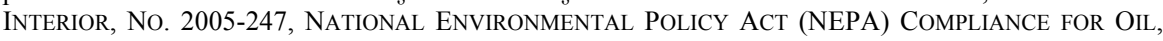
GAS, AND GEOTHERMAL DEVELOPMENT 2-1 (2005) [hereinafter BLM 2005 GUIDANCE]. Because the 390 CEs were not established pursuant to $\S 1508.4$, they are not subject to the requirement that actions "do not individually or cumulatively have a significant effect on the human environment." 40 C.F.R. $\S 1508.4$.

15. GAO EPACT REPORT, supra note 5, at 39. However, the GAO noted that some field offices use 390 CEs even when the proposed O\&G wells are located in areas of critical environmental concern. $I d$.

16. See id. at 21 (describing the concerns of industry officials).

17. W. Energy All., 2011 WL 3738240, at *5.

18. GAO EPACT REPORT, supra note 5, at 41 .

19. Id. at 41-42.

20. Id. at 47 . 
for permitting individual wells, there is an incentive to use Section 390 whenever possible, and to avoid larger-scale development plans (and larger-scale NEPA analysis). In avoiding an EIS or EA in favor of a CE, however, the BLM may miss an opportunity to minimize environmental impacts by grouping wells or sharing roads, pipelines, and infrastructure among wells. ${ }^{21}$ Consequently, the use of Section 390 CEs "has led to a spider-web pattern of development," where well sites are haphazardly spread across the landscape with little regard for optimal well, road, and infrastructure placement. ${ }^{22}$

In sum, because of Section 390, some O\&G projects may be being permitted more rapidly than before "without careful analysis" 23 or the opportunity for robust public involvement. The critical question addressed in this paper is: Does the expedited Section 390 CE permitting processlacking the careful agency analysis, transparency, and public participation found in both EAs and EISs - result in more environmentally impactful decisions than those made after EA or EIS review? This study addresses the question by comparing the environmental impacts of O\&G projects that have undergone different levels of NEPA review: Section 390 CE, EA, or EIS.

\section{BACKGROUND}

\section{A. The Bureau of Land Management and Oil and Gas Development}

The BLM is "The Nation's Largest Landlord," 24 administering 246.4 million surface acres of federal lands. ${ }^{25}$ Additionally, the BLM administers a 700 million acre federal subsurface mineral estate. ${ }^{26}$ The Mineral Leasing Act of 1920, as amended by the Federal Onshore Oil and Gas Leasing Reform Act of 1987, authorizes the BLM to grant leases for the "economically sound and stable" development of oil and gas on federal

21. See Del. River Keeper Network v. Fed. Energy Regulatory Comm'n, 753 F.3d 1304, 1313 (D.C. Cir. 2014) (“An agency impermissibly 'segments' NEPA review when it divides connected, cumulative, or similar federal actions into separate projects and thereby fails to address the true scope and impact of the activities that should be under consideration.").

22. GAO EPACT REPORT, supra note 5, at 36 .

23. Robert B. Keiter, Breaking Faith with Nature: The Bush Administration and Public Land Policy, 27 J. LAND, RESOURCES, \& ENVTL. L. 195, 202 (2007).

24. See generally JAMES R. SKILLEN, THE NATION'S LARgeSt LANDLORD: THE BuREAU OF LAND MANAGEMENT IN THE AMERICAN WEST (2009) (referring to the Bureau of Land Management as the "nation's largest landlord").

25. Bureau of Land Mgmt., Public Land Statistics 2014, Public Land Statistics, May 2015, at 7 [Public Land Statistics 2014].

26. Id. 
lands and private lands where the federal government owns the subsurface mineral estates. ${ }^{27}$

Pursuant to the Federal Land Policy and Management Act of 1976, the BLM uses a multi-step process when permitting oil and gas development. ${ }^{28}$ The first step involves the BLM drafting a Resource Management Plan (RMP). ${ }^{29}$ RMPs are regional land use plans intended to be broad guides for the long-term management of public lands. ${ }^{30}$ RMPs inventory resources and establish allowable uses, constraints, and goals for the region. ${ }^{31}$ Relevant to $O \& G$ development, the RMP designates areas as open or closed to development and determines general stipulations and mitigation requirements. ${ }^{32}$ The RMP does not approve site-specific decisions, but merely determines what areas are appropriate for certain uses. ${ }^{33}$ All subsequent $O \& G$ permitting must conform to the RMP governing the lands at issue, or the RMP must be amended to accommodate the use. ${ }^{34}$

After adopting an RMP, the BLM may lease areas for O\&G development. ${ }^{35}$ Before offering areas for leasing, the BLM reviews whether leasing conforms to the governing RMP and any NEPA documents applicable to the project or project area. ${ }^{36}$ The pre-leasing review is known as a determination of NEPA adequacy and is used to determine whether additional NEPA documentation is required. ${ }^{37}$ If the potential leases are consistent with the RMP and other NEPA documentation, then additional NEPA analysis may not be necessary at this stage,$^{38}$ and the BLM can offer lands for competitive bids and lease those lands to the highest bidder. ${ }^{39}$

\footnotetext{
27. Mineral Leasing Act, 30 U.S.C. $\S \S 181-226$ (2012); Federal Onshore Oil and Gas Leasing Reform Act, Pub. L. No. 100-203, 101 Stat. 1330-256, 1330-257 to -258 (1987).

28. $\quad 43$ U.S.C. $\S 1701$.

29. BLM's Competitive Oil and Gas Leasing \& Drilling Process, WILDERNESS SOC'Y 1, http://wilderness.org/sites/default/files/OG-Process-Fact-Sheet-Full.pdf [https://perma.cc/4S6S-5CL8] (last visited May 8, 2017).

30. $\quad 43$ C.F.R. $\S 1601.0-5(n)(2014)$.

31. 43 U.S.C. $\$ 1712 ; 43$ C.F.R. $§ 1601.0-5(n)(4)$.

32. Bureau of Land Mgmt., U.S. DeP'T of the InTerior, H-1601-1, Land Use PLANNING HANDBOOK 23 (2005).

33. 43 C.F.R. $\S 1601.0-5(n)(8)$ ("[The RMP] is not a final implementation decision on actions which require further specific plans, process steps, or decisions under specific provisions of law and regulations.").

34. $\quad 43$ C.F.R. $\S 1610.5-3(a)$.

35. 30 U.S.C. $\$ 226(\mathrm{a})$.

36. Pennaco Energy, Inc. v. U.S. Dep't of the Interior, 377 F.3d 1147, 1162 (10th Cir. 2004).

37. Id.

38. See N.M. ex rel. Richardson v. Bureau of Land Mgmt., 565 F.3d 683, 717-18 (10th Cir. 2009) (holding that the decision to conduct NEPA at the leasing stage is a fact specific determination and there is "no bright line rule that site-specific analysis may wait until the APD stage"). $39 . \quad 30$ U.S.C. $\S 226(\mathrm{~b})(1)(\mathrm{A})$.
} 
After leasing, the operator must submit an Application for Permit to Drill (APD) for each well. "No drilling operations, nor surface disturbance ... may be commenced prior to ... approval of the permit." The permit to drill on a lease is only granted after "analysis and approval ... of a plan of operations covering proposed surface-disturbing activities within the lease area." ${ }^{42}$ APD permitting requires NEPA compliance. ${ }^{43}$ NEPA analysis conducted at the APD stage generally ties to, and incorporates by reference, the existing RMP. ${ }^{44}$

\section{The BLM in Wyoming}

In 2014, Wyoming led the nation in natural gas, coal, uranium, trona, and bentonite production and was second in the nation in oil production. ${ }^{45}$ The BLM administers 18.3 million surface acres and 41.6 million subsurface acres in Wyoming. ${ }^{46}$ In 2015 , there were 14,747 O\&G leases extending across 9.9 million acres of these BLM lands. ${ }^{47}$ In 2014 , these leases produced 44 million barrels of oil and 1.2 trillion cubic feet of natural gas. ${ }^{48}$

The Buffalo Field Office, located in north-central Wyoming, is one of ten BLM field offices in the state. ${ }^{49}$ The Buffalo Field Office administers 780,291 acres of surface lands and 4.7 million acres of subsurface mineral lands encompassing three counties. ${ }^{50}$ These lands contain "vast deposits of oil, gas, and coal and provide[] a variety of resources such as wildlife habitat and rangelands for livestock grazing." ${ }^{, 51}$ In 2007, the Buffalo Field Office's administered lands produced approximately $18 \%$ of Wyoming's 
total oil production. ${ }^{52}$ As of 2008, federal O\&G leases covered approximately 2.5 million acres or approximately $55 \%$ of the subsurface mineral acres administered by the Buffalo Field Office. ${ }^{53}$ The 2001 Buffalo Field Office RMP and subsequent amendments guided the office's O\&G permitting until approval of a new RMP in $2015 .{ }^{54}$ These RMPs and their amendments provide broad management objectives as well as identify lands that are opened, closed, or subject to restrictions for $O \& G$ development over the period of time addressed in this analysis. ${ }^{55}$

\section{B. The National Environmental Policy Act (NEPA)}

NEPA is a procedural statute that requires federal "agencies to take a hard look at the consequences of a proposed action" before authorizing that action. ${ }^{56}$ NEPA "does not mandate particular results, but simply prescribes the necessary process." ${ }^{, 57}$ Even though NEPA is primarily a procedural statute, the EIS process can, in the context of O\&G development, reduce environmental impacts with relatively minor economic consequences. ${ }^{58}$

NEPA requires all federal agencies to prepare an EIS for "every recommendation or report on proposals for legislation and other major Federal actions significantly affecting the quality of the human

52. Bureau of Land Mgmt., Draft Resource Management Plan and Environmental Impact Statement for the Buffalo Field Office Planning ARea, at xlix (2013).

53. Id. at xxxvii.

54. Bureau of Land Mgmt., Approved Resource Management Plan for Public LANDS ADMINISTERED BY THE BUFFALO FIELD OFFICE 2 (2001). The 2003 Powder River Basin RMP and the 2011 Fortification Creek RMP amend portions of the 2001 Buffalo Field Office RMP relating to O\&G development. See generally Bureau of Land Mgmt., DeP'T of the InTERIOR, Final RESOURCE MANAGEMENT Plan and ENVIRONMENTAL IMPaCt Statement FOR the POWDER River BASIN OIL AND GAS PROJECT 1-5 (2003) (describing consultation and coordination efforts) [hereinafter POWDER RIVER EIS]; see generally BUREAU OF LAND MGMT., DEP'T OF THE INTERIOR, FORTIFICATION Creek Planning Area Resource Management Plan Amendment 1-3 (Aug. 2011) (one of the subsequent amendments); BUREAU OF LAND MGMT., DEP'T OF THE INTERIOR, RECORD OF DECISION and Approved Resource Management Plan Amendments fOR the Rocky Mountain Region, InCLUDing the Greater SAGe-Grouse Sub-Regions of LEWISTOWN NORTH DAKOTA NORTHWEST COlorado Wyoming AND the ApProved Resource Management Plans for Billings, Buffalo, Cody, Hiline, Miles City, Pompeys Pillar national Monument, South Dakota, [and] WORLAND (2015) [hereinafter BUFFALO 2015 RMP].

55. POWDER RIVER EIS, supra note 54, at 5-1.

56. Robertson v. Methow Valley Citizens Council, 490 U.S. 332, 356 (1989).

57. Id. at 350; Vt. Yankee Nuclear Power Corp. v. Nat. Res. Def. Council, Inc., 435 U.S. 519, 558 (1978) ("NEPA does set forth significant substantive goals for the Nation, but its mandate to the agencies is essentially procedural.").

58. John Ruple \& Mark Capone, NEPA—Substantive Effectiveness Under a Procedural Mandate: Assessment of Oil and Gas EISs in the Mountain West, 7 GEO. WASH. J. ENERGY \& ENVTL. L. 39, 46-47 (2016). 
environment." ${ }^{49}$ Federal agencies may, as an initial step, prepare an EA to determine whether the environmental impact of the proposed action is significant enough to warrant an EIS. ${ }^{60}$ The EA is a "concise public document" that "[b]riefly provide[s] sufficient evidence and analysis for determining whether to prepare an [EIS]." ${ }^{\prime 61}$ If the proposed action is found to have no significant effect, the agency completes the NEPA review by issuing a finding of no significant impact. ${ }^{62}$ However, if the proposed action is determined to have a significant effect, then an EIS is required. ${ }^{63}$ Additionally, an agency may forego an EA and proceed directly to an EIS if the consequences of the action are clearly significant. ${ }^{64}$

An EIS must evaluate the proposed action, reasonable alternative actions, and a "no action" alternative, comparing each alternative's direct, indirect, and cumulative environmental impacts. ${ }^{65}$ The "no action" alternative reflects the scenario where the proposed activity does not take place and provides a baseline against which to compare a project's alternative impacts. ${ }^{66}$ Consideration of alternatives is "the heart of the environmental impact statement, ${ }^{, 67}$ and consideration of fewer alternatives may result in decisions with more environmental effects. ${ }^{68}$

As a first step in completing an EIS, the agency publishes a notice of intent to prepare an EIS in the Federal Register, describing the proposed action. ${ }^{69}$ Next, after receiving and considering public comment, the agency prepares and circulates a draft EIS for public review and comment. ${ }^{70}$ After reviewing and responding to comments and making any appropriate changes to the EIS, the agency then circulates the final EIS. ${ }^{71}$ Finally, the agency selects an approved alternative and issues a record of decision. ${ }^{72}$

If the action falls within a category of actions that can be authorized under a CE, then the agency need not prepare an EIS or an EA. ${ }^{73} \mathrm{CEs}$ are

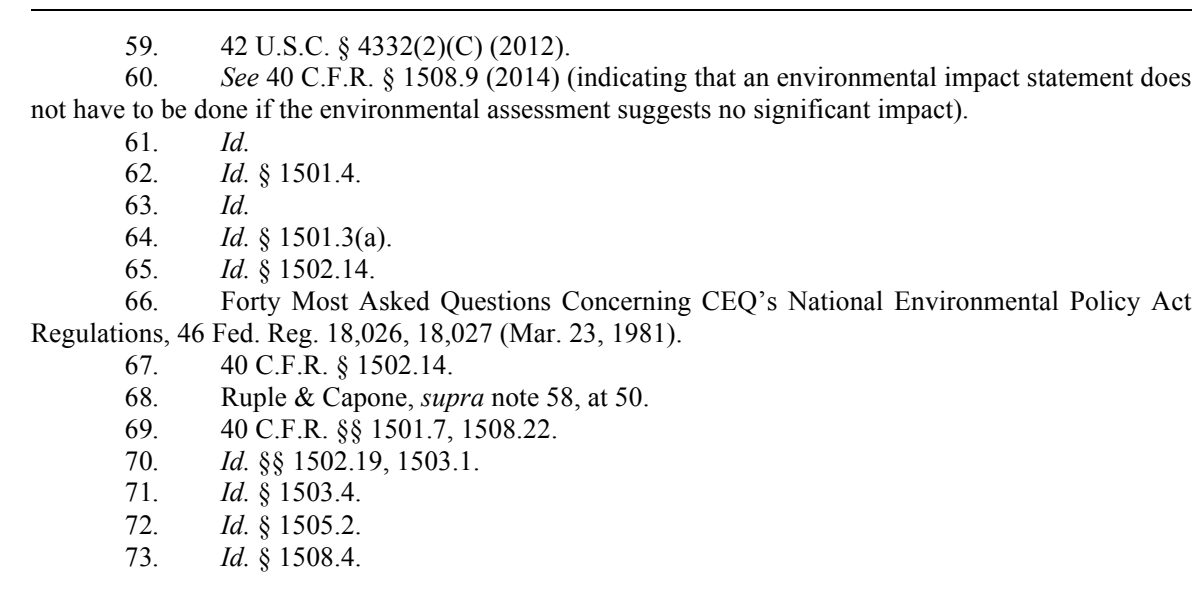


specific types of actions identified by the agency through rulemaking, which do not individually or cumulatively have a significant effect on the human environment. ${ }^{74}$ Federal agencies are required to design procedures for establishing CEs. ${ }^{75}$ The agencies' CE procedures "shall provide for extraordinary circumstances in which a normally excluded action may have a significant environmental effect," in which case an EA or EIS will be required. ${ }^{76}$ The BLM has not established CEs that apply specifically to O\& $\mathrm{G}$ development. ${ }^{77}$

\section{Section 390 of the Energy Policy Act of 2005}

In Section 390 of the EPAct, Congress identified five categories of action subject to a "rebuttable presumption" that they are categorically excluded from NEPA. ${ }^{78}$ Three of the CEs apply directly to the permitting of new O\&G wells. ${ }^{79}$ Shortly after Congress enacted the EPAct, the BLM adopted guidance that directs Section $390 \mathrm{CE}$ use. ${ }^{80}$

Under Section 390, Type 1 CEs are available when the proposed well site results in less than five acres of disturbance and when site-specific analysis has been previously completed in another NEPA document "so long as the total surface disturbance on the lease is not greater than 150 acres." If more than one well is proposed for the project, each well is counted separately and each may disturb up to five acres, but all contribute to the 150 -acre disturbance cap. ${ }^{82}$ Type 2 CEs are available when the operator proposes to drill an oil or gas well from an existing well pad where

74. Id. $\S \S 1508.4,1507.3(\mathrm{~b})(1)-(2)(\mathrm{ii})$.

75. Id. $\S 1508.4$.

76. Id. The BLM has identified twelve extraordinary circumstances, including actions that: (1) have significant impacts on threatened or endangered species or species proposed for listing, (2) contribute to the spread of noxious weeds or invasive species, and (3) have a "direct relationship to other actions with individually insignificant but cumulatively significant environmental effects." NEPA HANDBOOK, supra note 6, at 155.

77. See NEPA HANDBOOK, supra note 6, at apps. 3, 4 (listing department and bureau CEs).

78. $\quad 42$ U.S.C. § 15942(a) (2012); GAO EPACT REPORT, supra note 5, at 34. The EPAct "does not specify what the 'rebuttable presumption' provision in Section 390 means or how BLM is supposed to implement it." Id. The BLM interprets the "rebuttable presumption" to mean that a Section 390 CE "will comply with NEPA unless this presumption is rebutted by showing that one or more of the [Section 390] required conditions is not present." Id. at 40-41. For example, one may rebut the presumption that a Type $1 \mathrm{CE}$ applies by showing that the project will result in more than five acres of surface disturbance per well. Under this interpretation, the existence of extraordinary circumstances alone, however, is insufficient to rebut the presumption of CE applicability.

79. $\quad 42$ U.S.C. $\$ 15942$.

80. BLM 2005 GUIDANCE, supra note 14.

81. 42 U.S.C. $\$ 15942(b)(1)$.

82. BLM 2005 GUIDANCE, supra note 14, at 2-2. 
drilling has occurred within the past five years. ${ }^{83}$ Type 3 CEs are available when the project proposes to drill a "well within a developed field for which an approved land use plan or any environmental document prepared pursuant to NEPA analyzed such drilling as a reasonably foreseeable activity" and was completed within five years of drilling. ${ }^{84}$ The BLM guidance defines a developed field as any field in which a confirmation well has been completed. ${ }^{85} \mathrm{~A}$ confirmation well is one that demonstrates that "oil and gas resource[s] exist in paying quantities" for the field. ${ }^{86}$ The BLM guidance also states that RMPs, encompassing the proposed well, will satisfy the NEPA requirement for Type 3 CEs so long as the RMP "contains a reasonably foreseeable development scenario broad enough to encompass this action." $" 87$

The BLM's 2005 guidance provided that Section 390 CEs would not be subject to extraordinary circumstances. ${ }^{88}$ This represents an important difference from administrative CEs, which cannot be used when extraordinary circumstances exist. ${ }^{89}$ The 2005 BLM guidance states that field offices "should apply [a Section $390 \mathrm{CE}$ ] unless the activity does not meet the standard prescribed in the law to qualify for the exclusion ... [and field offices are] advised not to prepare a NEPA document in lieu of appropriately applying the statutory [CE]." 90 The use of CEs must be documented, and the document "must include a brief narrative in the well file stating the rationale for making the determination that the categorical exclusion applies." ${ }^{91}$

The BLM's Failed Attempt to Adopt New Section 390 Guidance

Early application of Section 390 CEs and the BLM guidance led to "disagreements and litigation," prompting Congress to direct the Governmental Accountability Office (GAO) to report on the use and benefits of Section 390 CEs. ${ }^{92}$ The GAO's main finding was that "[a] lack

88. Id.; see also Megan J. Anderson, The Energy Policy Act and Its Categorical Exclusions: What Happened to the Extraordinary Circumstance Exception?, 28 J. LAND, RESOURCES, \& ENVTL. L. 119, 128 (2008) ("This means, for example, when an oil and gas development project that falls under $\S 390[\mathrm{CE}]$ is in sensitive habitat area, there is no exception to the [CE] application.”). 
of clarity in Section 390 and BLM's guidance has raised serious concerns about the use of [S]ection 390 [CEs]. ${ }^{, 93}$ In 2010, in response to the GAO report and a court settlement, the BLM adopted new guidance that made "substantial" changes to its Section 390 CE procedures. ${ }^{94}$

The 2010 guidance directed field offices "to conduct a review of extraordinary circumstances when considering use of any of the Section 390 [CEs]." 95 Further, under the 2010 guidance, field offices should permit the action only after an EA or EIS when extraordinary circumstances are present. ${ }^{96}$ Specific to Type 3 CEs, the 2010 guidance stated that CEs could not rely "solely on an approved land use plan and associated EIS." 97 Instead, the proposed wells in a Type $3 \mathrm{CE}$ must have been "adequately analyzed in an existing activity-level or project-specific EIS or EA." 98 The guidance also required that Type 2 CEs only be used if the proposed drilling site was adequately analyzed in a project-specific EA or EIS. ${ }^{99}$

In 2011, the Western Energy Alliance, an O\&G trade association, sued the BLM, alleging that the BLM's 2010 guidance document violated the Administrative Procedure Act (APA) ${ }^{100}$ and Section 390 of the EPAct. ${ }^{101}$ Noting that the BLM's 2010 guidance was a "complete 'about-face" from their prior guidance, the court held that the 2010 guidance constituted "legislative rules adopted contrary to public notice and procedures required by [the APA]." 102 The court vacated and enjoined the 2010 guidance nationwide on APA grounds. ${ }^{103}$ The court did not reach the issue of the guidance violating Section 390 of the EPAct. ${ }^{104}$

Following the decision in Western Energy Alliance, the BLM instructed all field offices that the 2010 guidance was no longer valid and

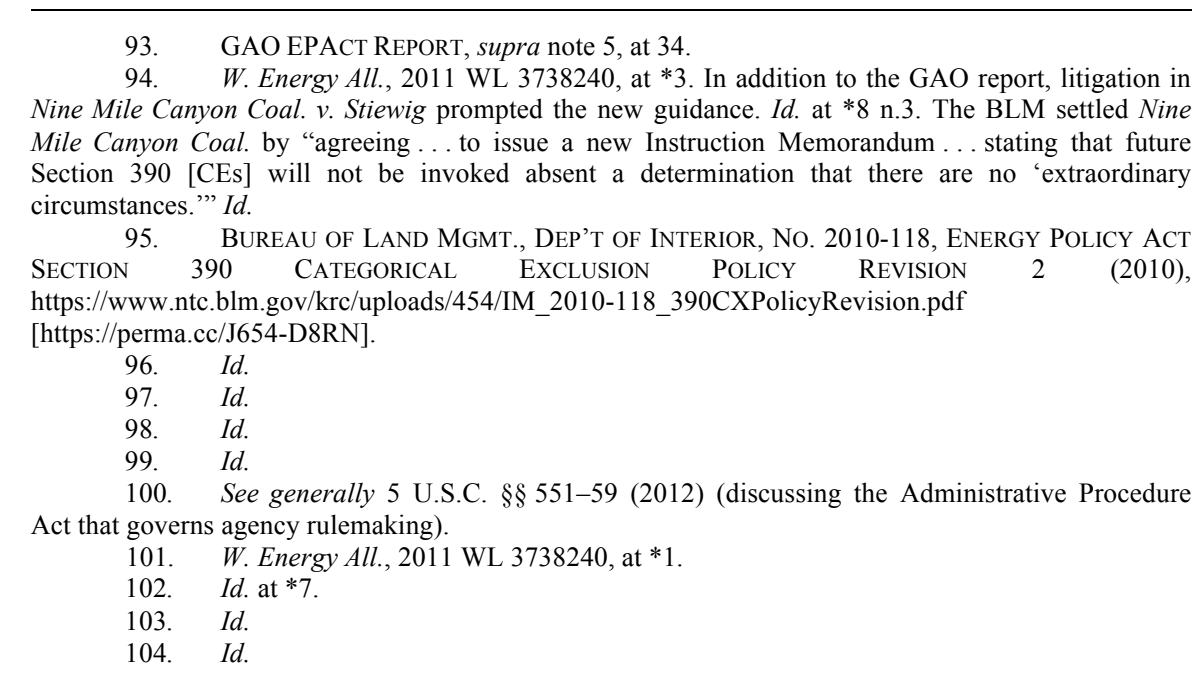


to follow the 2005 guidance instead. ${ }^{105}$ However, the BLM indicated its intent to initiate rulemaking to establish new guidelines for the use of Section 390 CEs. ${ }^{106}$ At the time of writing this article, the BLM has not published a proposed rule to this effect.

\section{METHODS}

\section{A. Geographic Scope and Data Acquisition}

The BLM tracks NEPA compliance at three different levels: national, state, and field office. A brief survey revealed irregular and incomplete tracking across the three levels. In general, field offices maintained the most complete records, but even then, some field offices did not track all EAs and CEs. Our initial survey is consistent with the GAO's finding that national BLM data regarding the number of CEs issued "varied considerably from . . . data supplied ... directly by the field offices."107

At the national level, the BLM recently launched a nationwide register for NEPA planning. ${ }^{108}$ This site allows the public to "review and comment online on BLM NEPA and planning projects... [and] makes finding documents easier." 109 At present, the national register is not fully implemented and provides only a fraction of NEPA decisions from a limited number of BLM field offices. ${ }^{110}$

At the state level, the BLM maintains state NEPA compliance websites in the four states addressed in our earlier work: Colorado, Montana, Utah, and Wyoming. ${ }^{111}$ However, the state offices across these four states vary in terms of their approach to CE and EA dissemination. For example, the Utah BLM office has a central online database that attempts to track NEPA compliance for all field offices in the state, ${ }^{112}$ but cross-referencing the data

105. Impacts to Onshore Jobs, Revenue, and Energy: Review and Status of Sec. 290 Categorical Exclusions of the Energy Policy Act of 2005: Oversight Hearing Before the Subcomm. on Energy \& Mineral Res. of the H. Comm. on Nat. Res., 112 ${ }^{\text {th }}$ Cong. 52-55 (2011) (testimony of Mike Pool, Deputy Director Bureau of Land Mgmt.).

106. Id.

107. GAO EPACT REPORT, supra note 5, at 14.

108. National Register for Land Use Planning and National Environmental Policy Act Documents, BUREAU OF LAND MGMT., DEP'T OF THE INTERIOR, https://eplanning.blm.gov/epl-frontoffice/eplanning/nepa/nepa_register.do [hereinafter BLM National Register] (last visited Jan. 12, 2017).

109. Id.

110. Id.

111. Regions, BUREAU LAND MGMT., https://www.blm.gov/locations [HTTPS://PERMA.CC/48CJ-UL49] (last visited Jan. 20, 2017).

112. Utah Planning and NEPA, BUREAU LAND MGMT., https://www.blm.gov/programs/planning-and-nepa/plans-in-development/utah $\quad[$ https://perma.cc/J668VSUD] (last visited Jan. 20, 2017). 
available through this state database with information from field office websites revealed that the state database was missing numerous EAs and CEs. Montana provided a seemingly complete record of EAs and CEs organized by field office, but the actual NEPA documents are not available for download and must be requested from the issuing field office. ${ }^{113}$ Wyoming organized NEPA documents by field office; however, not all field offices tracked CEs. ${ }^{114}$

In many cases, a separate field office website also provides access to NEPA documents specific to that field office. Information obtained from individual field offices, however, was highly inconsistent, with some field offices displaying and making available only EISs and EAs and others providing a list of all NEPA decisions without providing downloadable documents.

At the time of writing, the Buffalo Field Office in Wyoming had the most complete online NEPA record of any field office surveyed. Consequently, the Buffalo Field Office was selected for this study. It is also within the geographic scope of our previous analysis of O\&G NEPA decisions, ${ }^{115}$ allowing for comparison with EIS data from the previous study.

\section{B. Variables for Analysis}

All Buffalo Field Office EAs and CEs quantified the number of wells and well pads proposed and permitted. However, initial surface disturbance was the only environmental variable reported consistently throughout the EAs and CEs. ${ }^{116}$ Initial surface disturbance reflects the amount of ground and vegetation disturbance that occurs with initial well-site development and includes well-pad construction, road construction and improvement of existing roads, utility and pipeline construction, and construction of other

\footnotetext{
113. Public Participation and NEPA Compliance on Public Lands in Montana and the Dakotas, BUREAU LAND MGMT., http://www.blm.gov/mt/st/en/info/nepa.html [https://web.archive.org/web/20160929013744/http://www.blm.gov/mt/st/en/info/nepa.html] (last visited Jan. 19, 2017).

114. Wyoming Planning and NEPA, BUREAU LAND MGMT., https://www.blm.gov/programs/planning-and-nepa/plans-in-development/wyoming [https://perma.cc/6LFR-BLGM] (last visited Jan. 25, 2017).

115. Ruple \& Capone, supra note 58, at 41.

116. Long-term or life-of-project disturbance was reported in many documents, however, the methods for determining this variable varied. Because the methods for calculating long-term disturbance varied and because the temporal scope of long-term disturbance depended on several factors - including reclamation efforts by the operator and construction schedules as well as site specific environmental conditions - this variable was not included in the analysis.
} 
facilities associated with the production of O\&G. ${ }^{117}$ Many documents separated the total initial surface disturbance by the activity, resulting in disturbance acreage for well pads, roads, and other facilities.

\section{Initial Surface Disturbance as an Indicator of Environmental Impact}

This analysis focuses on initial surface disturbance because it was recorded consistently and because initial surface disturbance also has broad implications for plants and wildlife, water quality, and air quality. ${ }^{118}$ Initial surface disturbance can result in loss of wildlife habitat, habitat fragmentation, and behavioral disruption in some species. ${ }^{119}$ It can cause the spread of nonnative species through the clearing of native vegetation combined with the use of contaminated machinery. ${ }^{120}$ Further, it exposes soils to wind and water erosion. ${ }^{121}$ Wind eroded soils can be major contributors to air pollution. ${ }^{122}$ Water eroded soils can impair water quality through increased sediment and nutrient levels. ${ }^{123}$

In the study area, the BLM recognizes that approximately $82 \%$ of initial surface disturbance will last the life of the project. ${ }^{124}$ Long-lasting impacts include roads, well pads, and other facilities that will remain in place until the $\mathrm{O} \& \mathrm{G}$ is depleted and the lands are completely reclaimed. The remaining $18 \%$ of the initial disturbance is temporary in nature and typically involves areas surrounding the actual facilities that are necessarily

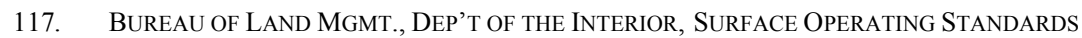
AND GUIDELINES FOR OIL AND GAS EXPLORATION AND DEVELOPMENT 15-16, 19, 36 (2007).

118. Bureau of Land MgMt., Dep'T OF the InTERIor, Proposed Resource Management Plan and Final EnVironmental Impact Statement for the Buffalo Field OfFice PlanNing AREa 845 (2015) ("Surface disturbance associated with oil and gas development activity is the primary indicator of effects on other resources.").

119. Alison G. Lyon \& Stanley H. Anderson, Potential Gas Development Impacts on Sage Grouse Nest Initiation and Movement, 31 WILDLIFE SOC'Y BULL. 486, 490 (2003); Joseph M. Northrup \& George Wittemyer, Characterising the Impacts of Emerging Energy Development on Wildlife, with an Eye Towards Mitigation, 16 ECOLOGY LETTERS 112, 116 (2013).

120. See Jonathan L. Gelbard \& Jayne Belnap, Roads as Conduits for Exotic Plant Invasions in a Semiarid Landscape, 17 CONSERVATION BIOLOGY 420, 421 (2003) (discussing roadside herbicide treatments as a proposed explanation for native and nonnative vegetation disturbances).

121. J. Belnap \& D.A. Gillette, Disturbance of Biological Soil Crusts: Impacts on Potential Wind Erodibility of Sand Desert Soils in Southeastern Utah, 8 LAND DEgRADATION \& DEV. 355, 361 (1997).

122. Christopher Houser \& William G. Nickling, The Emission and Vertical Flux of Particulate Matter < 10 $\mu$ m from a Disturbed Clay-Crusted Surface, 48 SEDIMENTOLOGY 255, 255-56 (2001).

123. David N. Wear et al., Land Cover Along an Urban-Rural Gradient: Implications for Water Quality, 8 ECOLOGICAL APPLICATIONS 619, 627-28 (1998).

124. POWDER RIVER EIS, supra note 54, at 2-41. 
disturbed during construction and which are reclaimed shortly after construction. ${ }^{125}$

\section{Dataset}

We obtained and reviewed all 176 O\&G well permitting CE ( $\mathrm{n}=94)$ and EA $(n=82)$ documents completed by the Buffalo Field Office between January 1, 2011, and December 31, 2014. Notably, the Buffalo Field Office did not complete a single O\&G EIS during this period.

We reviewed every $\mathrm{CE}$ and EA and recorded the following indicators, if available: (1) number of proposed and permitted wells; (2) number of proposed and permitted well pads; (3) acreage of proposed and permitted initial surface disturbance; (4) acreage of permitted initial surface disturbance caused by well-pad construction; (5) acreage of permitted initial surface disturbance caused by road construction and improvement; and (6) acreage of permitted initial surface disturbance caused by other facilities.

To allow for comparison of CEs and EAs to EISs, we used an EIS dataset compiled for a previous study. ${ }^{126}$ That EIS dataset includes EISs completed for large O\&G development projects by the BLM or United States Forest Service in Colorado, Montana, Utah, or Wyoming. ${ }^{127}$ The dataset includes 13 EISs completed between 2004 and October of $2014 .^{128}$

\section{Data Analysis}

We sought to compare project impacts between CEs, EAs, and EISs. Two types of CEs, Type $1(n=15)$ and Type $2(n=2)$ CEs are used less frequently. These CEs allow for permitting of very small projects or projects that drill from an existing well pad. ${ }^{129}$ Because of their specialized nature and low sample size in the dataset, we did not statistically compare Type 1 and 2 CEs to EAs and EISs. In contrast, Type 3 CEs $(n=77)$ are the most commonly used Section 390 CEs nationally and were the most commonly used CE in this study. ${ }^{130}$ Type 3 CEs allow permitting within

125. Bureau of LAND MGMt., DeP'T OF THE INTERIOR, WY-070-02-065, DRAFT ENVIRONMENTAl IMPact STATEMENT AND DRAFt PlanNing AMENDMENT FOR THE POWDER River BASIN OIL AND GAS PROJECT 240-41 (2002).

126. Ruple \& Capone, supra note 58, at 41.

127. Id.

128. Id.

129. 42 U.S.C. $\$ 15942(b)$.

130. GAO SECTION 390 REPORT, supra note 7, at 6 ("Section 390 [Type 3 CEs] account for more than 60 percent of the section 390 categorical exclusions used to approve APDs [between 2006 and 2008]."). 
developed fields; they are not bound by the surface disturbance limitations of a Type $1 \mathrm{CE}$ or the Type $2 \mathrm{CE}$ 's requirement that wells be drilled from an existing well pad. ${ }^{131}$ Consequently, we describe impacts from all three types of CEs but statistically compare only Type 3 CEs with EAs and EISs.

We reviewed initial surface disturbance per well for Type 3 CEs, EAs, and EISs with an Analysis of Variance test (ANOVA) using JMP Pro 11.2 statistical software. If the ANOVA indicated a statistically significant effect, we then used a post-hoc Each Pair, Student's t-Test to locate the source of the significant effect. We consider a value of $\mathrm{P}<0.05$ as statistically significant and a value of $\mathrm{P}<0.10$ as trending toward statistical significance.

We used a weighted mean for our analysis. ${ }^{132}$ A weighted mean allows for consideration of grouped data when those groups are different in size. ${ }^{133}$ This was necessary in our study because the sampling unit is the individual NEPA decision. Each NEPA decision permitted a different number of wells that could vary considerably from project to project. For example, a $\mathrm{CE}$ may permit a single well, while an EIS may authorize several thousand wells. Consequently, an arithmetic mean calculation would inaccurately represent the data because each NEPA decision would be weighted equally regardless of the number of wells it permitted. ${ }^{134}$ To capture the true mean value for surface disturbance per well, we needed to weigh each decision by the number of wells it permitted. Thus, NEPA decisions that permitted more wells were given more weight than those that permitted less based on the total number of wells permitted by the decision.

To better understand the components of surface disturbance, we used the same methods as described for initial surface disturbance to compare per well surface disturbance caused by well pads, road construction, and other facilities for EIS, EA, and Type 3 CE decisions.

\section{RESULTS}

Between January 1, 2011, and December 31, 2014, the Buffalo Field Office issued 176 O\&G NEPA decisions. ${ }^{135}$ These decisions permitted

\footnotetext{
131. Id. at 5 .

132. See Brian P. Macfie \& Philip M. Nufrio, Applied Statistics for Public Policy 73 (2006) (explaining the significance and application of a weighted mean).

133. See Lisa F. Smith et AL., The ART And Practice of Statistics 58 (2008).

134. Id.

135. BLM National Register, supra note 108 (under "ePlanning Project Search," select "NEPA." Then put "Wyoming" into the "State(s)" column, and select "All" offices, "All" document types, and "All" fiscal years. Finally, select "Fluid Minerals" under "Program(s)" and hit "search").
} 
1,268 wells through $82 \mathrm{EAs}, 94 \mathrm{CEs}$, and no EISs. The vast majority of CEs were Type 3.

The 94 CEs permitted 310 wells on 224 well pads and allowed for a total of 2,415.2 acres of initial surface disturbance. Of the 94 CEs, 15 were Type 1 CEs, 2 were Type 2 CEs, and 77 were Type 3 CEs. Type 1 CEs permitted an average of 1.87 wells (range $=1$ to 6 ) from an average of 1.6 well pads (range $=0$ to 6 ). ${ }^{136}$ Initial surface disturbance for Type 1 CEs averaged 5.9 acres (range $=0.4$ to 20.5). Each of the two Type 2 CEs permitted a single well from an already existing well pad and caused no new initial surface disturbance. Type 3 CEs permitted an average of 3.6 wells (range $=1$ to 22 ) from 2.6 well pads (range $=0$ to 15 ). On average, Type $3 \mathrm{CE}$ projects caused 30.2 acres of initial surface disturbance (range $=0.82$ to 165 ).

Forty-three of the $94 \mathrm{CEs}$ did not include gathering pipelines, electrical utilities, other production facilities, or some combination of these ancillary facilities in the analysis. If these facilities became necessary, the operator agreed to notify the BLM through a sundry notice. ${ }^{137}$ Sixty-six percent of the Type 1 CEs (10 of 15$)$ and $43 \%$ of the Type 3 CEs (33 of 77) did not include these associated facilities. Consequently, initial surface disturbance values for Type 1 and 3 CEs may underestimate total development impacts because wells are likely to require additional infrastructure.

The 82 EAs permitted 958 wells on 697 well pads, allowing for a total of 4,260.2 acres of initial surface disturbance. On average, each EA permitted 11.7 wells (range $=0$ to 84 ) drilled from 8.5 well pads (range $=0$ to 80 ). The average initial surface disturbance permitted per EA was 53.2 acres (range $=0$ to 417.9). Only one EA denied all proposed well applications. ${ }^{138}$ Several EAs deferred judgment on individual wells contained in the larger proposal until additional information could be obtained or further analysis was completed. ${ }^{139}$

\footnotetext{
136. Several Type 1 and Type 3 CEs permitted the drilling of new wells from existing well pads.

137. See infra Part IV.B.1 and associated text.

138. See generally BuREAU OF LAND MGMT., DEP'T OF THE INTERIOR, No. WY-070-EA13-3, Environmental Assessment: Yates Petroleum Corp. 3 (2012) (stating denial of all proposed wells).

139. See, e.g., Bureau of LAND MGMt., DeP'T OF THE InTERIOR, No. WY-070-EA14-203, ReCord of DECISION: PEAK POWDER River Resources 1-2 (2014) (approving one well site and deferring decision on several others).
} 
Comparison of Surface Disturbance for CEs, EAs, and EISs

The EISs analyzed in our earlier work were prepared for larger proposals than those considered in the EAs or CEs. ${ }^{140}$ EIS decisions permitted, on average, 3,618.85 wells (range=138 to 28,200 ). ${ }^{141}$ The proposed surface disturbance for EIS projects was, on average, 1,802.28 acres (range $=788$ to 55,150). ${ }^{142}$ In comparison, the proposed surface disturbance for EA and CE projects was, on average, 55.20 acres (range $=0$ to 417.9 ) and 30.22 acres (range $=0.82$ to 165 ), respectively. The number of wells per well pad were similar across the three NEPA types with Type 3 CEs averaging 1.41 wells per pad, EAs averaging 1.37 wells per pad, and EISs averaging 1.22 wells per pad.

\begin{tabular}{|l|l|l|l|}
\hline & \multicolumn{1}{|c|}{$\begin{array}{c}\text { Type 3 } \\
\text { CE }\end{array}$} & \multicolumn{1}{|c|}{ EA } & \multicolumn{1}{|c|}{ EIS } \\
\hline $\mathrm{N}$ & 77 & 82 & 13 \\
\hline Total Wells & 277 & 958 & 47,045 \\
\hline $\begin{array}{l}\text { Total Well } \\
\text { Pads }\end{array}$ & 200 & 697 & 38,562 \\
\hline $\begin{array}{l}\text { Total } \\
\text { Disturbance }\end{array}$ & $2,325.40$ & $4,260.20$ & $23,429.64$ \\
\hline Avg. Wells & 3.6 & 11.7 & $3,618.85$ \\
\hline Avg. Pads & 2.6 & 8.5 & $2,966.30$ \\
\hline $\begin{array}{l}\text { Avg. } \\
\text { Disturbance }\end{array}$ & 30.2 & 53.2 & $1,802.28$ \\
\hline $\begin{array}{l}\text { Avg. } \\
\text { Disturbance } \\
\text { per Well }\end{array}$ & 8.31 & 4.45 & 2.70 \\
\hline
\end{tabular}

Table 1: Summary of Impacts Permitted

\section{ANOVA Results}

EIS projects resulted in the lowest amount of surface disturbance per well $(\mathrm{M}=2.70$ acres, $\mathrm{SE}=1.69) .{ }^{143} \mathrm{EA}$ projects had the second lowest surface disturbance per well $(\mathrm{M}=4.45$ acres, $\mathrm{SE}=0.92)$. Type $3 \mathrm{CE}$ projects resulted in the most surface disturbance per well $(\mathrm{M}=8.31$ acres, $\mathrm{SE}=1.69)$.

\footnotetext{
140. Ruple \& Capone, supra note 58.

141. Id. at 44 .

142. Id. at 45 .

143. "M" represents weighted mean and "SE" represents standard error.
} 
EIS surface disturbance per well was significantly lower than that of EAs $(\mathrm{p}=0.046)$ and Type 3 CEs $(\mathrm{p}=0.012)$. The difference between EA and Type $3 \mathrm{CE}$ surface disturbance per well was trending toward statistical significance $(\mathrm{p}=0.055)$.

\section{Components of Initial Surface Disturbance}

The differences in surface disturbances per well are largely controlled by road and well-pad-construction disturbances. Not all NEPA decisions separated overall surface disturbance into categories of disturbance, so we only reported on those decisions that did $(n=169)$. Because we reported on a subset of our data, the sum of the weighted means for the three categories of disturbance does not equal the weighted mean total initial surface disturbance reported above in Comparison of Surface Disturbance for CEs, EAs, and EISs. ${ }^{144}$

\begin{tabular}{|l|cc|cc|cc|}
\hline & \multicolumn{2}{|c|}{ Type 3 CE } & \multicolumn{2}{c|}{ EA } & \multicolumn{2}{c|}{ EIS } \\
\cline { 2 - 7 } & Mean & SE & Mean & SE & Mean & SE \\
\hline $\begin{array}{l}\text { Road } \\
\text { Construction } \\
\text { Disturbance }\end{array}$ & 3.34 & 0.76 & 1.71 & 0.45 & 0.7 & 0.09 \\
\hline $\begin{array}{l}\text { Well-Pad } \\
\text { Construction } \\
\text { Disturbance }\end{array}$ & 4.03 & 0.53 & 1.7 & 0.32 & 1.9 & 0.07 \\
\hline $\begin{array}{l}\text { Other } \\
\text { Construction } \\
\text { Disturbance }\end{array}$ & 1.34 & 0.39 & 0.66 & 0.24 & 0.86 & 0.05 \\
\hline
\end{tabular}

Table 2: Disturbance (per Well) by Activity and Level of NEPA

Documentation

Type $3 \mathrm{CE}$ projects resulted in the greatest amount of road-construction disturbance per well $(\mathrm{M}=3.34$ acres, $\mathrm{SE}=0.76)$. EA projects had slightly less road-construction disturbance $(\mathrm{M}=1.71$ acres, $\mathrm{SE}=0.45)$. EIS projects resulted in the least amount of road-construction disturbance $(\mathrm{M}=0.70$ acres, $\mathrm{SE}=0.09)$. The difference between EISs and both CEs $(\mathrm{p}=0.0007)$ and EAs $(\mathrm{p}=0.032)$ was statistically significant. The difference between EAs and CEs was trending toward statistical significance $(p=0.065)$.

144. See supra notes 140-42 and accompanying text. 
Similarly, Type $3 \mathrm{CE}$ projects resulted in the greatest amount of wellpad-construction disturbance per well $(\mathrm{M}=4.03$ acres, $\mathrm{SE}=0.53)$. EA projects had slightly less well-pad-construction disturbance $(\mathrm{M}=1.70$ acres, $\mathrm{SE}=0.32$ ). EIS projects resulted in the least amount of well-padconstruction disturbance $(\mathrm{M}=1.90$ acres, $\mathrm{SE}=0.07)$. The difference between EISs and CEs was statistically significant $(p=0.0002)$. The difference between EAs and CEs was also statistically significant $(p=0.0001)$. There was no significant difference between EISs and EAs ( $\mathrm{p}=0.52)$.

The catchall category, other facilities, accounts for all other wellassociated disturbances that occur outside the well-pad or road footprint. Other facilities may include pipelines and utility lines not within road corridors, compressor sites, evaporation pits, production facilities, and storage tanks. Other facilities caused similar levels of disturbance per well for EIS $(\mathrm{M}=0.86$ acres, $\mathrm{SE}=0.05)$ and $\mathrm{EA}$ projects $(\mathrm{M}=0.66$ acres, $\mathrm{SE}=0.24)$. Type $3 \mathrm{CEs}$ had slightly more other-facility disturbance per well $(\mathrm{M}=1.34$ acres, $\mathrm{SE}=0.39)$. None of these differences are statistically significant.

\section{DISCUSSION}

\section{A. Comparison of Environmental Effects for Different Levels of NEPA Compliance}

Even though $43 \%$ of Section 390 Type 3 CEs likely underestimated actual project impacts by omitting certain facilities, ${ }^{145}$ projects permitted through Type 3 CEs still had greater environmental effects per well than those that underwent EA or EIS review. Type $3 \mathrm{CE}$ wells disturb, on average, 3.86 acres more per well than EA wells, and, on average, 5.61 acres more per well than EIS wells. The difference between Type $3 \mathrm{CE}$ projects and EA and EIS projects is largely driven by greater road- and well-pad-construction disturbance in Type $3 \mathrm{CE}$ projects.

The increased road surface disturbance we observed for Type 3 CEs may reflect insufficient and piecemeal planning caused by numerous operators acting independently. ${ }^{146}$ This explanation is consistent with the GAO's observation that Section $390 \mathrm{CE}$ use has caused a haphazard "spider-web pattern of development" as operators and the BLM take a "piecemeal approach to [field] development." 147 Under a more

\footnotetext{
145 See infra Part IV.B.1 and accompanying text.

146. Bureau of Land Mgmt, Dep't of the Interior, Proposed Casper Resource MANAGEMENT Plan AND Final ENVIRONMENTAL IMPACt STATEMENT D-11 (2007).

147. GAO EPACT REPORT, supra note 5, at 36, 47.
} 
comprehensive approach to development, like that analyzed in EAs and EISs, road location can be optimized so that less road area is necessary to access wells. ${ }^{148}$ Optimization occurs when operators consider existing and future $O \& G$ development within the field. The operator can then locate their facilities to utilize existing roads or align roads to minimize redundancies.

Likewise, piecemeal planning and development may also explain the increased well-pad disturbance we observed in Type 3 CE projects. ${ }^{149}$ Many projects that underwent EA or EIS review minimized well-pad footprints by using centralized facilities. ${ }^{150}$ A centralized facility is one that is located so that it may provide service to numerous well pads. By centralizing production, storage, or compression-station facilities, operators can reduce the size of well pads as the well pads no longer need to accommodate these facilities. In the current study, Type $3 \mathrm{CE}$ projects seldom incorporate centralized facilities.

Centralized facilities can also reduce road-construction surface disturbance, as centralized facilities often reduce or eliminate the need for heavy truck traffic to individual well pads. ${ }^{151}$ By reducing heavy truck volume to individual well pads, the operators can use "lower road standards which may result in less [surface disturbance]." 152 Roads with lower standards tend be narrower and require less surface disturbance per mile than roads constructed for high volumes of trucking. ${ }^{153}$

148. See Bureau of Land Mgmt., Surface Operating Standards and Guidelines FOR OIL AND GAS EXPLORATION AND DEVELOPMENT 41 (2007) [hereinafter THE GOLD BOOK] (recommending that a well-sited all-weather road negates the need for other roads). "Transportation planning can ... prevent unnecessary surface disturbance.... Proper road location can significantly reduce or eliminate impacts to ... environmental resources." Id. at 21. Consideration of existing and future O\&G development in the project area can result in more efficient road location by eliminating redundant roads. $I d$. at 23 .

149. Richard Champion, Rocky Mountain Mineral Law Found., Forming THE Unit - Why Unitize? The Industry Perspective 7 (2006) (explaining that piecemeal development can "result in each separate lease being drilled without regard to optimum operating practices. Separate storage facilities might be constructed for each lease. Separate gathering lines, roads, rights of way and trucking activity ... result[ing] in inefficiencies and increased costs").

150. See Bureau of Land Mgmt., U.S. Dep'T of the Interior, Interior DeCision: West Tavaputs Plateau DeVelopment Plan 21 (2010) (requiring the operator to "centrally locate production equipment" and storage tank batteries and thereby reducing overall surface disturbance by reducing the size of individual well pads); BUREAU OF LAND MGMT., U.S. DEP'T OF THE INTERIOR, NO. BLM/WY/PL-06/006+1310, Final ENVIRONMENTAL IMPACT STATEMENT JONAH INFILL DRILLING PROJECT 2-22 (2006) ("All new development and production facilities... would be placed at centralized locations to accommodate multiple wells, unless [it is] proven ... not [to] be technically or economically feasible, or that another method would create less environmental impact.").

151. Presentation, Bureau of Land Mgmt., Wildlife Management: Best Management Practices for Fluid Minerals (Nov. 2006) (on file with journal).

152. Id.

153. THE GOLD BOOK, supra note 148, at 23-24. 
Public participation may also explain the difference in surface disturbance per well observed in this study. The external reform theory postulates that increased transparency and public involvement associated with the NEPA process may result in more sustainable decision-making. ${ }^{154}$ Public comment during the EIS process can influence the creation of alternatives and final agency decisions. ${ }^{155}$ However, public comment and disclosure are not required for CE decisions. ${ }^{156}$ It is unclear whether operators would voluntarily deploy environmentally beneficial technologies or use central facilities absent the public participation engendered by the EA and EIS process. ${ }^{157}$ Thus, the increased surface disturbance we observed for Type $3 \mathrm{CE}$ projects may, in part, be due to insufficient external pressure on both the BLM and operators.

In sum, Type $3 \mathrm{CE}$ projects are likely to cause greater environmental impact per well than projects that undergo EA or EIS review. These differences are likely the result of piecemeal planning and reduced external pressure on the operators and the BLM. The 3.86 acres of difference in surface disturbance per well between Type $3 \mathrm{CE}$ projects and EA projects may seem minor; however, if our results hold at the national level, the use of Type 3 CEs may be permitting tens of thousands of acres of avoidable surface disturbance per year.

\section{B. Specific Problems in Section 390 CE Implementation}

\section{Sundry Notices}

Sundry notices are requests from the operator to the BLM for modification of an approved APD ${ }^{158}$ Sundry notices can be used for a "wide range of activities," such as expanding or moving a well site or adding pipelines. ${ }^{159}$ The BLM commonly uses a separate Section 390 CE to

154. Robert V. Bartlett, The Rationality and Logic of NEPA Revisited, in ENVIRONMENTAL POLICY AND NEPA 55-56 (Ray Clark \& Larry Canter eds., 1997).

155. Ruple \& Capone, supra note 58, at 50 ("[S]everal EISs included alternatives emphasizing directional drilling and consolidated well pads that were developed in response to public comments.").

156. GAO EPACT REPORT, supra note 5, at 41-42.

157. See Bureau of Land Mgmt., Dep'T of the Interior, Final Environmental

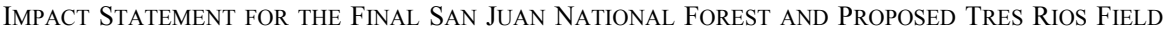
OFFICE LAND AND RESOURCE MANAGEMENT Plan 491 (2013) (explaining that directional drilling can be more costly for operators than conventional vertical wells, and that without some external driver, there is little incentive for operators to deploy the technology).

158. 43 C.F.R. § 3162.3-2 (2014).

159. GAO EPACT REPORT, supra note 5, at 13. 
permit sundry-notice requests. ${ }^{160}$ However, BLM guidance documents are silent about the proper use of Section 390 CEs for sundry-notice approval. ${ }^{161}$ The

BLM's failure to provide information on when and if it is appropriate to use [S]ection 390 [CEs] to approve sundry notices has raised concerns for some that BLM field offices are using the exclusions inappropriately and that [the] BLM is not being transparent about how the [S]ection 390 [CEs] are used. ${ }^{162}$

Forty-six percent of all CEs we reviewed $(n=43)$ did not include potentially necessary surface-disturbing facilities (e.g., gathering pipelines, electrical utilities, other production facilities, or some combination of these ancillary facilities) in the analysis. In these cases, the operators agreed to provide the BLM with a sundry notice if the wells became producers and additional facilities were necessary. Forty-three percent of Type 3 CEs $(n=33)$ omitted potentially necessary facilities. Type 3 CEs can only be used for new "well[s] within a developed field." ${ }^{63}$ Within a developed field, the BLM should expect that the well will produce in paying quantities, and the BLM should disclose all potentially necessary facilities in the $\mathrm{CE}$ to avoid underestimation of environmental impacts.

Sixty-six percent of the Type 1 CEs $(n=10)$ omitted potentially necessary facilities. Type $1 \mathrm{CEs}$ are limited to five acres of surface disturbance, so omission of surface-disturbing facilities from the analysis may result in the application of this CE for activities that would otherwise require potentially more complicated forms of NEPA review. ${ }^{164}$ While we are not accusing operators of intentional misrepresentations, operators do have a clear incentive to omit gathering pipelines and production facilities whenever possible in order to remain below the five-acre threshold, thereby meeting the criteria of the CE and avoiding the delays of an EA or EIS. Notably, half of the Type $1 \mathrm{CE}$ decisions that omitted facilities had surface impacts greater than four acres. In these cases, additional facilities may have pushed the project's total surface disturbance over the five-acre threshold.

160. See, e.g., 42 U.S.C. § 15942(b)(5) (2012) (serving as the catch-all CE); GAO EPACT REPORT, supra note 5, at 13.

161. GAO EPACT REPORT, supra note 5, at 32.

162. Id. at 33 .

163. 42 U.S.C. $\$ 15942(b)(3)$.

164. Id. $\S 15942(\mathrm{~b})(1)$. 
The BLM should consider providing guidance for the omission of facilities and use of sundry notices in the context of Section 390 CEs. Specifically, the BLM should require operators to disclose and account for all facilities that will likely become necessary.

\section{Type 3 CEs Tiered to RMPs}

Type 3 CEs require that "an approved land use plan or any environmental document prepared pursuant to NEPA analyzed such drilling as a reasonably foreseeable activity" and was completed within five years of drilling. ${ }^{165}$ RMPs encompassing the proposed well satisfy the NEPA requirement, so long as the RMP "contains a reasonably foreseeable development scenario broad enough to encompass this action." 166 This may be problematic, as "RMPs typically cover several million acres[] [and] may [simply] lack the resolution needed to adequately assess the resources and environmental impacts that will result from subsequent development."167 Consequently, RMPs are poorly suited to address impacts occurring at the smaller geographic scale of an APD. ${ }^{168}$

The Type 3 CEs in the current study all incorporated the Buffalo Field Office RMP and subsequent amendments into their analysis. The RMP was amended most recently in 2015, ${ }^{169}$ incorporating new, reasonably foreseeable development scenarios for each alternative considered and projecting between 7,630 and 12,892 total productive wells. ${ }^{170}$ The 2015 RMP appears sufficient to satisfy the Type 3 CE criteria. The RMP is "an approved land use plan" that "analyzed such drilling as a reasonably foreseeable activity" and was completed within five years of drilling. ${ }^{171}$ However, all the Buffalo Field Office Type 3 CEs considered here predate

\footnotetext{
165. Id. § 15942(b)(3).

166. BLM 2005 GUIDANCE, supra note 14, at 2-4.

167. John Ruple \& Mark Capone, NEPA, FLPMA, and Impact Reduction: An Empirical Assessment of BLM Resource Management Planning and NEPA in the Mountain West, 64 ENVTL. L. 953, 956-57 (2017)

168. Id.; see also Land-Use Issues Associated with Onshore Oil and Gas Development: Joint Oversight Hearing Before the Subcomm. on Nat'l Parks, Forests \& Pub. Lands \& the Subcomm. on Energy \& Mineral Res. of the H. Comm. on Nat. Res., 110th Cong. 3-4 (2007) (testimony of John Emmerich, Deputy Director of the Wyoming Game \& Fish Department) ("The level of analysis, disclosure and recommended mitigation that is appropriate for sensitive wildlife corridors and crucial habitat is not provided in programmatic land use plans such as RMPs... [it], can only be achieved through a more in depth analysis provided by an EA or in most cases an EIS.").

169. BUFFALO 2015 RMP, supra note 54.

170 Bureau of Land Mgmt., Dep'T of the Interior, Proposed Resource Management Plan and Final EnVironmental Impact Statement for the Buffalo Field OFFICE PLANNING AREA apps 1941 (2015).

171. $\quad 42$ U.S.C. $§ 15942$ (b)(3) (2012).
} 
the 2015 RMP and incorporated one or more previously completed sitespecific EAs into their analysis. Although the Buffalo Field Office went beyond the requirements of Section 390, our surface-disturbance results indicate that incorporating a previously completed RMP or EA without any additional analysis may not provide the same level of environmental benefits as conducting an EA or EIS for the project.

\section{Type 3 CEs Tiered to Master Leasing Plans}

Many RMPs are more than five years old and, therefore, cannot be used to support either Type 1 or Type $3 \mathrm{CE}$ issuance. Furthermore, new information or changed conditions may require reconsideration of decisions contained in existing RMPs. Recognizing these issues and that wholesale RMP revision could be an unwieldy tool in adapting to such changes, the BLM in 2010 introduced a series of leasing reforms affecting O\&G development on public lands. ${ }^{172}$ These reforms required the BLM to conduct a more in-depth review for areas that are or may be opened to leasing and where additional planning and analysis is needed prior to new O\&G leasing because of changing circumstances, updated policies, and new information. ${ }^{173}$ The additional planning and analysis is contained in a Master Leasing Plan (MLP) and accompanying NEPA documentation. The MLP is ordinarily initiated as a land-use-plan amendment and reconsiders RMP decisions pertaining to leasing. ${ }^{174}$

As an RMP amendment prepared pursuant to NEPA that specifically addresses $O \& G$ development as a reasonably foreseeable activity, MLPs are a predicate decision upon which either a Type 1 or a Type 3 CE can be based. MLPs may, therefore, prove to be an important tool in expediting O\&G development because many RMPs are more than five years old and could not be tiered to support a section 390 CE but for an MLP. Thus, MLPs may breathe new life into older RMPs, at least as they integrate with Section 390 for O\&G permitting purposes.

\section{Recommendation to the BLM}

The BLM should consider, through notice-and-comment rulemaking, establishing regulations that require review for extraordinary circumstances

172. BurEaU OF LAND MGMT., OIL AND GAS LEASING REFORM LAND USE PLANNING AND LEASE PARCEL REVIEWS 1 (2010).

173. Bureau of Land Mgmt., Comparison of Process Changes Resulting From BLM LEASING REFORM POLICY (2010).

174. Bureau of Land Mgmt., DeP'T. OF the InTERIOR, No. 2010-117, Oil and Gas LEASING REFORM - LAND USE PLANNING AND LEASE PARCEL REVIEWS (2010). 
prior to Section $390 \mathrm{CE}$ use. This would ensure that O\&G projects involving sensitive resources undergo EA or EIS review. For projects with moderate impacts, operators may be more willing to voluntarily reduce impacts to ensure the applicability of a Section 390 CE. Projects with minor environmental impacts would likely be unaffected by extraordinarycircumstance regulation and receive Section $390 \mathrm{CE}$ review. Such a regulation would be consistent with the EPAct for three reasons.

First, the EPAct does not expressly preclude extraordinarycircumstances review. ${ }^{175}$ According to the GAO, whether the language of Section 390 subjects CEs to extraordinary-circumstances review is a question "open to differing interpretations." interpret the interaction of NEPA and the EPAct as excluding [extraordinary-circumstances review]." 177 Five years later, the BLM changed course and attempted to require extraordinary-circumstances review by adopting new guidance. ${ }^{178}$ However, the BLM's new guidance was vacated because it failed to follow APA procedures. ${ }^{179}$ The federal court did not reach the issue of whether extraordinary-circumstances review was consistent with the EPAct. ${ }^{180}$ Thus, the plain language of Section 390 is ambiguous with regard to the applicability of extraordinary circumstances.

Second, the language Congress used in Section 390 indicates an intent that extraordinary-circumstances review would apply. ${ }^{181}$ If Congress had intended for the Section 390 CEs to entirely circumvent the Council on Environmental Quality's (CEQ) regulations requiring extraordinarycircumstances review, they could have done so expressly. By using the term "categorical exclusions," Congress borrowed a term of art that was created and defined by CEQ regulations. ${ }^{182}$ "It is a cardinal rule of statutory construction that, when Congress employs a term of art, it presumably knows and adopts the cluster of ideas that were attached to each borrowed word in the body of learning from which it was taken." 183 "In such case, absence of contrary direction may be taken as satisfaction with widely

\footnotetext{
175. Anderson, supra note 88 , at 129.

176. GAO EPACT REPORT, supra note 5, at 34.

177. Anderson, supra note 88, at 129.

178. Holt Statement, supra note 8 .

179. W. Energy All., 2011 WL 3837240, at*3.

180. Id.

181. Anderson, supra note 88, at 129.

182. Kevin H. Moriarty, Circumventing the National Environmental Policy Act: Agency Abuse of the Categorical Exclusion, 79 N.Y.U. L. REV. 2312, 2313 (2004) (stating that NEPA, as enacted, had "no clear limits on its application"). omitted).

183. Fed. Aviation Admin. v. Cooper, 566 U.S. 284, 292 (2012) (internal quotations
} 
accepted definitions, not as a departure from them." ${ }^{184}$ Under this rule of statutory interpretation, Section 390 "adopted the cluster of ideas" surrounding the term "categorical exclusion," including the requirement of extraordinary-circumstances review.

Third, the language Congress chose not to use in Section 390 indicates an intent that the CEs be subject to CEQ regulations, such as the extraordinary-circumstances requirement. Congress knows how to exempt Section 390 CEs from the CEQ regulations if it wants to do so. Congress has exempted several types of action from both NEPA and the CEQ regulation. ${ }^{185}$ To do so, Congress has proclaimed, as it did in the Stafford Act, that the action "shall not be deemed a major federal action significantly affecting the quality of the human environment within the meaning of [NEPA]." ${ }^{186}$ In the Regional Rail Reorganization Act of 1973, Congress used slightly different language: "[T]he provisions of [NEPA] shall not apply with respect to any action taken under authority of this chapter." ${ }^{\text {187 }}$ Because Congress knows how to expressly exempt activities from NEPA and the CEQ regulations, its decision not to include similar express language in the EPAct suggests that the omission was deliberate. ${ }^{188}$ It follows that Section 390 CEs should be subject to the same regulations as administrative CEs because to do otherwise would treat Section 390 as creating a complete exemption to NEPA, not merely a categorical exclusion to it.

184. Morissette v. United States, 342 U.S. 246, 263 (1952); GAO EPACT REPORT, supra note 5, at 40. The "rebuttable presumption" language in Section 390 does not constitute contrary direction from Congress. Id. "Rebuttable presumption" is not defined by the EPAct or the NEPA case law. Id. There is no reason to assume that the "rebuttable presumption" is meant to exempt the Section 390 CEs from the CEQ regulations if a project meets the Section 390 CE criteria. Id. The "rebuttable presumption" could mean that projects are presumed not to have significant effects on the human environment. $I d$. at 41 . This presumption can be rebutted by showing extraordinary circumstances exist. Id.

185. See, e.g., Federal Water Pollution Control Act Amendments of 1972, 33 U.S.C. $\S \S 1251-1388$ (2012) (exempting actions under the CWA from NEPA 33 U.S.C. $§ 1371(c)(1)$ ); Energy Supply and Environmental Coordination Act of 1974, 15 U.S.C. § 793(c)(1) (2012) (stating that no action taken shall be deemed a major Federal action under NEPA); Regional Rail Reorganization Act of 1973, 45 U.S.C. § 791 (2012) (excluding NEPA and CEQ regulations); Stafford Act, 42 U.S.C. § 5159 (2012) (exempting the Stafford Act from apply to NEPA).

186. 42 U.S.C. \$ 5159.

187. 45 U.S.C. $\$ 791(\mathrm{c})$.

188. See NLRB v. Bildisco \& Bildisco, 465 U.S. 513, 522-23 (1984) ("Obviously, Congress knew how to draft an exclusion for collective-bargaining agreements when it wanted to; its failure to do so in this instance indicates that Congress intended that $\$ 365$ (a) apply to all collectivebargaining agreements covered by the NLRA."); see N. Singer, STATUTES AND STATUTORY CONSTRUCTION $\S 51.02$, at 199 (6th ed. 2000) ("[I]f words used in a prior statute to express a certain meaning are omitted, it will be presumed that a change of meaning was intended."). 


\section{CONCLUSION}

In 2005, Congress created several statutory CEs to expedite environmental review of O\&G development projects on federal lands. ${ }^{189}$ Since that time, the BLM has permitted as much as $28 \%$ of all wells using the statutory CEs instead of conducting NEPA analysis through an EA or EIS. ${ }^{190}$ This has led to "disagreements and litigation" over the appropriate application and environmental consequences of Section 390 CEs. ${ }^{19}$

Our results show that Section 390 Type 3 CEs, the most commonly used CE, result in projects with greater surface area disturbance per well than projects that have undergone EA or EIS review. Increased surface disturbance in Type $3 \mathrm{CE}$ projects appears to be a result of piecemeal road planning and failure to utilize centralized facilities. It is also likely that reduced public participation in the Section 390 process removes an external-pressure component that can influence both operator and BLM decision-making.

We recognize the limited geographic scope of the current study; however, if our results are representative of national trends, then the use of Type 3 CEs may be permitting tens of thousands of acres of avoidable surface disturbance every year. This is environmental harm that may have been avoided if projects underwent EA or EIS review.

In light of these findings, we urge caution when considering proposals to expedite the NEPA process because expedited review may come at the cost of increased environmental harm. We hope this study will help inform the BLM as it prepares to propose new Section $390 \mathrm{CE}$ regulations. We recommend that the BLM considers incorporating extraordinarycircumstances review into its Section $390 \mathrm{CE}$ process. This action could ameliorate some of the environmental harms we observed while still allowing expedited permitting for projects with truly minor impacts.

189. Energy Policy Act of 2005, Pub. L. No. 109-58, § 390, 119 Stat. 594, 748 (2005).

190. GAO SECTION 390 REPORT, supra note 7.

191. W. Energy All., 2011 WL 3738240, at*3. 